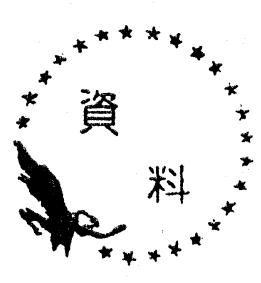

石炭組織学の立場からみたコークス

強度推定法の問題点

一昭和 44 年 10 月 1 日石岸科学会議講演—

\section{1. 緒言}

実験室的に簡単に実施できる精度の高いコークス強 度推定法があれば現場の日常作業管理，あるいは插入 炭配合管理などに対し，はかり知れない利益をあたら すことはいうまであない。

コークス強度推定法は各国で研究され, わが国で あ, 城1などの研究があるが, 石炭組織学的方法に立 脚した推定法は U. S. Steel その他二, 三の研究所で 開発され，現在屯なお引続き検討されていて，かなり 実用化されてきている。これらの方法に刺戟され， 城, 奥原, 高橋は八幡製鉄所に入荷する各国炭種の性 状を調べて, 組織学的なコークス強度推定法の適否を 検討し独自の簡便法を発展して, 充分満足すべき結果 がえられだ。しかしながら，低石炭化度炭，とくに国 内炭を輸入炭に加えてコークスを作るばあいには，推 定值と実測值の間にはかなりの誤差を生じ, 開発した 簡便法はなお十分だとはいいがたかった。本論では， 節分分別した綱上，網下を検討しながら組織成分とコ 一クス強度との直接, 間接的な関連, および組織成分よ りコークス強度を推定する方法の問題点を検討する。

\section{2. 石炭組織学的コークス強度推定法概説}

石炭組織を構成する微細組織成分 (Maceral) には 数種のものがありおのおのはその物理・化学成分を異 にするが石炭加熱時に熔融・流動するあのを活性成分, しからざるものを不活性成分に大別することができる マセラルの性状は石炭化にともなって変化し, 活性マ セラルも終わりには不活性になるが，石炭化度に対応 するマセラルの 活性度=膠結力を求め, 石炭中に共 存する活性 : 不活性成の量比を勘案してその石炭から えられるコークス強度を推定するというのが本推定法 の骨子である。本来, 強度推定に当たっては各活性成分 の膠結力はその都度各マセラルについて测定してコー クス強度を算定す心゙きであるが，一般に石炭活性成分

* 城博, 奥原捷晃, 山口徳二, 高橋良平：「石炭組 織学的方法飞よるコークス强度推定法」を昭和 40 年10月, 九州鉱山学会にて奥原が講演
九州大学理学部 高橋良平・永井利明

の90\%以上が Vitrinite であるのでての膠結力を求め て全活性成分の総合膠結力とする方法がとられている し, さらに Virinite の膠結力についてあすでに多く の資料があり，とくに Ammosov の詳しい測定值が 発表されているので, 普通には Virinite タイプの分 布を求めるだけで翏結力分布を求めコークス強度をて れをあとにして算定するという方法がとられてい

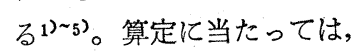

Composition-Balance-Index(Inert Index)と Strength Index の二つのパラメーターを計算し Iso-Tumbler Index Curve 因にプロットして求めるが Schapiro, Harrison らの結果ではタンブラー強度 $25 \mathrm{~m} \mathrm{~m}$ 指数の 計算値と実測值は驚くほどよく一致し, 日常の作業管 理や混炭量の決定などに実用されている。

さて，筆者の 1 人高橋は，八幡製鉄所コークス研究 室と協同で同所に入荷する各国産原料炭についてての 方法が妥当であるか否かを検討し，新たに等潰裂強度 線図を作成した。これはタンブラ一強度 $25 \mathrm{~mm}$ 指数よ りあ潰裂強度 $15 \mathrm{~mm}$ 指数の方が実用性が高いととが認 められているためである。 Inert Index, Strength Index は従来の方法でそのまま計算し, $15 \mathrm{~mm}$ 指数図 にプロットするものであるが，各種外国炭および北松 炭の計算值之実測值の関係を検討すると相関係数は

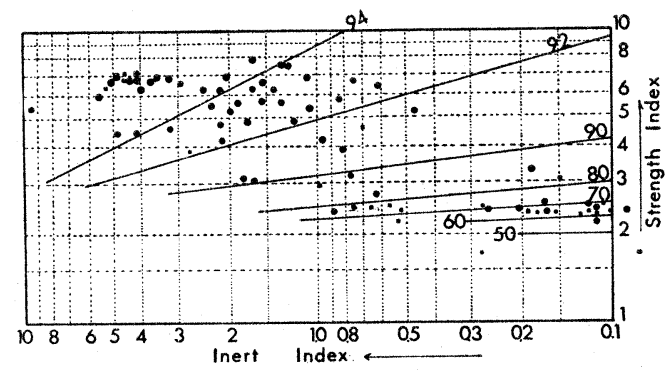

- Deviation between experimental and calculated values $\leq 2 \%$

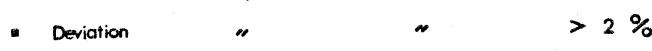

Fig. 1 Diagram showing relationship between Strength Index, Inert Index and Drum Index $(>15 \mathrm{~mm})$ 
$r=0.95(n=66)$ であり高度に有意で強い相関々係を 示しているととがわかった。なお, 両パラメーターを 計算するに当たっては日本炭特有の Degradinite は従 来実験の結果に従って活性成分とし Vitrinite 量に換 算して計算した。なお，ての方法でコークス強度を推 定するにしてあ原炭のマセラル分析, Vitriniteタイプ の分布などかなりの時間と熟練を要する検鏡作業が前 提となるので, 短時間で測定できる揮発分とVitrinite タイプ分布の関係を求めてテーブルを作成し，マセラ ル分析と揮発分から両パラメーターを算定できるよう に簡便化した。ただし，乙の図の欠点は90-94の 15 $\mathrm{mm}$ 指数值の範囲は非常に広く，かなり細かい所まで 読みとることができるが，70以下の指数のばあいには 間隔が狭くなるために判読でかなりの誤差がでてくる ことである。しかしながら，実際問題としてはクリテ イカルな強度は85以上でありそれ以下のものではたと えその指数が71であろうが73であろうと適・不適を判 定するのには支障はなく，乙の欠点も致命的な欠陷に はなりえないと考えている。ただ，てのような図示上 の欠陥とは別に西九州, 北海道, 筑豊などの国内弱粘 結炭のコークス強度はこの方法による計算值とは大差 があり, またこれらの炭種と輸入炭の混炭からつくっ たコークスの強度であかなり偏差がでているので，乙 のランクの石炭化度炭に適用できない理由を求めるた め篩上, 節下コークス片を試料として改めてての推定 法を検討した。

\section{Vitrinite 加熱時の行動と笠上・節下コークス}

上記のようなコークス強度の組織学的な解析は一応 理論的に正しいと思われ，加熱炭の顕微鏡像ともよく 一致している6 ${ }^{6}$ 。とくに捚入原炭の粒度をかえるとい う単に物理的な変化だけでコークス強度が変化する現 象などは，他の論理よりもよりよく説明できる。しか しながら, この方法であ前述のように, 低石炭化度炭 コークスの推定值と実測值に大きな䛊差がおきている ので，その原因を求めるためまずコークス化過程を再 検し，乙の方法の適応限度を検討することとする。

石炭粒を加熱する時の顕微鏡像の変化についてはす でに本誌に 2 回にわたって報告しているので6)7詳 細 はくりかえさないが, Vitrinite粒の気泡発生, 熔融, 流 動, 固化 (結晶様子の晶出) は著しい顕微鏡像の変化 である。気泡発生は熔融, 流動がまだ顕微鏡的にあら われない温度段階で始まり，また大粒のVitriniteに 最初にみられるので, 石炭の Micro-pore に包蔵され ている遊離ガス, 吸着ガスの逸散がまず第一におこる ために気泡が生ずると思われる。ついで組織成分の熱
分解による脱ガス作用が引きつづいて気泡発生はます ます盛んとなり, 熔融, 流動がこれにつづき, その後 固化作用が行なわれてコークス化の大要はおわると考 えている。Taylorはコークス化過程で球状体 (Spherical body）が認められると報告しているが8) 筆者の国 内・外炭のコークス化ではまだ確認したことがないの でこの球状体が普通のコークス化過程で必ず生成され るあのか否か明らかでないし，また上記諸変化のいず れの段階でおてるのかさだかではない。しかし，固化 段階で晶出する結晶様子の配列, あるいはその異方性 の状態は,やはり球状体らしいものが生成し,てれがま だよく流動しえないVitriniteの中を動いたとした方が 解釈しやすい像を示しているので Spherical body が 石炭化のどてかの段階で生成されると推測してる*。気 泡は上記のように脱ガス作用でできたあのであるが, その後の乾留の進行によってタール，ピッチなどの低 分子のあのがこの気泡の周辺あるいはその中までに渗 出し，乙れが球状体となる可能性はないであろうか。 ピッチコークスと全く同じ顕微鏡像を示す部分が気泡 周辺にとくに多くできているてとはこの推定を支持す るものと思われる (Photo. 3，4)。

さて, ある石炭化度範囲に限ると低石炭化 度の Vitriniteは高石炭化度のあのより, よりよく流動する ことはプラストメーター試験によって知られている。 したがって熔融・流動して不活性成分をセメントし, ネットワークを作る難易だけからいえば低石炭化度の あのほどすぐれている。ただし，いうまでむなくコーク スの強度は壁・孔隙の性状, 両者の配列などによって 左右されるので, ある石炭化度炭から最強のコークス を作るための活性成分, 不活性成分の適性量化は各石 炭化ごとにあるにちがいない。全炭種にわたっててれ を実測したAmmosovの価は，したがって妥当である と判定すべきであるし，またてれを使った Composition-Balance Index, または Strength Index は当を えた指数と考えるべきであろう。

さて, イットマン，高島炭，およびおのおのを $50 \%$ 混炭して缶焼きコークスを作り潰裂強度を求めると Table 1 の結果がえられた。このうち25〜 $15 \mathrm{~mm}, 15 \sim$ $6 \mathrm{~mm},-6 \mathrm{~mm}$ 品試料を固結研磨し, 比較検討した。 検鏡結果はつぎのとおりである。

1) イットマン

*ピッチコークスの球状体を検討して和られる本田 英昌からも重要な示唆を頂き, 筆者の考えに御討 論を頂いた。記してここに氏そ感謝の意を表しま す。 
Table 1 潰裂強度試 験

\begin{tabular}{|c|c|c|c|c|c|c|c|c|}
\hline 試 料 粒 & $(\mathrm{m} / \mathrm{m})$ & +50 & +38 & +25 & +15 & +6 & -6 & loss \\
\hline \multirow{2}{*}{ Itmann } & 30 & 24. 40 & 73. 70 & 89.25 & 92.20 & 94.40 & 4. 90 & 0.70 \\
\hline & 150 & 4. 15 & 43.40 & 75.00 & 80.40 & 83.45 & 14. 35 & 2. 20 \\
\hline \multirow{2}{*}{ 島 } & 30 & 4. 45 & 15.70 & 32.45 & 59.55 & 88. 10 & 11.80 & 0.10 \\
\hline & 150 & 0 & 0 & 6.55 & 30.30 & 72.59 & 25.45 & 1.60 \\
\hline Itmann $50(\%)$ & 30 & 23. 25 & 60.30 & 85.85 & 90.35 & 94.00 & 5. 80 & 0.20 \\
\hline 高 島 $50(\%)$ & 150 & 4. 30 & 34.90 & 70.30 & 78.40 & 83. 15 & 15.60 & 1. 25 \\
\hline
\end{tabular}

a) $25 \sim 15 \mathrm{~m} \mathrm{~m}$

不活性成分として多量の Fusinite 片, Micrinite Sclerotinite が含有され，乙れを活性成分が十分 に熔結して厚い壁を作り，孔腺は均等に配列して いる。壁には小桿状の結晶様子がさまざまな方向 でモザイック状に配列し強い異方性を示すが，て れらより輝度, 異方性も高く幅の広い結晶様子*が かなりの量分布する。乙れは Micro-bandedであ りバンドとバンドの間がはなれているあのが多い がヘヤークラックは必ずしもとれとつながって発 生してはおらず,むしろ無関係に小桿状, Microbanded 状結晶様子をきっている（Photo. 1，2）。

b) $15 \sim 6 \mathrm{~m} \mathrm{~m}$

コークス壁の性状および孔隙の状態は，25～15 $\mathrm{mm}$ のあのと全く同じであり15〜6 $\mathrm{mm}$ の粒度 ンクになった差異が認められない。コークス粒周 辺をみてす不活性成分と熔結セメント部の所がき れて,外縁壁となったとも思われず,組織検鏡の結 果からは15〜6 m m粒度にならねばならない組織 的必然性はみとめられなかった（Phot. 3〜5)。

c) $-6 \mathrm{~mm}$

不活性成分片か微層状結晶様子片である。前者 は活性分にセメントされていないあのが大部分で コークス壁がこわれる際に結合力がよわくて，こ の部分でコークス壁がわれ，遊離して篩下におち あのである。一方微層状結晶子片は活性成分であ たり，本来不活性成分をセメントするものである が微層状の結晶様子の発達がよすぎたため厚くな

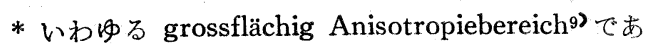
る。
りすぎ却って，層面で㔀離して節下に落ちたあの である (Photo. 6)。

2) 高島炭

a ) $25 \sim 15 \mathrm{~m} \mathrm{~m}$

高島炭には Micrinite は皆無であり Fusinite はきわめて少なく，またその他の不活性成分も少 ないの上, 活性成分がよく熔融, 流動しているた め, ネットワークは均質であるが壁はうすく, 孔 隙はイットマンのそれよりあ大きい。したがって 当然のことながら $25 \mathrm{~mm}$ 指数, $15 \mathrm{~mm}$ 指数 は低 い。壁には微粒の結晶様子しか晶出せず*, 局所 的には，等方性の部分屯認められるが，孔隙の周 辺には輝度が高く, 異方性の強い部分が生成し,さ らにごくまれに微層状結晶子がみとめられる。

b) $15 \sim 6 \mathrm{~mm}$

コークス壁，孔隙の性状は25～15 $\mathrm{mm}$ mものと 差異は認められない。またコークス塊周辺壁が内 部の壁と差異がないのはイットマンのばあいと 同様であり，組成上からは15〜 $6 \mathrm{~mm}$ になった理 由は検鏡では判然としない（Photo. 7,8)。

c) $-6 \mathrm{~mm}$

イットマンの- $6 \mathrm{~mm}$ と異なり，とくに破砕さ れやすいもの，脆いものからなっているわけでは なく, +6 mm のものと同じネットワークをもつ コークス片であるが，壁部には微粒結晶様子の晶 出が悪く,また壁も薄いものが多い（Photo. 9)。

3) イットマン高島混合炭コークス

a) $25 \sim 15 \mathrm{~m} \mathrm{~m}$

*いわゆる feinkörniger Anisotropiebereich ${ }^{9}$ 
イットマンに由来する結晶様子の多い部分之高 島炭の陰微晶質セメント部から構成されている が，その混在の仕方はきわめて複雑であり，いず れかが片寄って混在する部分は高島炭あるいはイ ットマンと同じ像を示す。両者がうまく混融して いるばあいの方がむしろ少ないが, 偏在していて も結晶子をうまく陰微晶質部がセメントしてい る。コークス塊縁辺部には高島炭の薄壁部かイッ トマンの微層状結晶子部が多い。

\section{b) $15 \sim 6 \mathrm{~mm}$}

前記同サイズのものと同様，組成的には $25 \sim 15$ $\mathrm{m} \mathrm{m}$ ののと差異は認められない。

\section{c) $-6 \mathrm{~mm}$}

Fusinite などの不活性成分を膠結物不足でよく セメントしていないもの，あるいは Fusinite に 微層状の結晶子がついたものが多い。またきわめ て薄壁の細片が多いが，乙れらは高島炭の薄壁と 同時に高反射輝度, 異方性の強いイットマン薄壁 部である (Photo. 10〜12)。

上記でわかるように，イットマンおよび混合炭では 不活性成分之活性成分の熔解・凝結の不十分なむのが 粉化し $6 \mathrm{~mm}$ 節下物となっているほか活性成分のうち 微層状晶子屯層面より剝離して節下物になっている。 前者は活性成分 : 不活性成分比の大小に由来するすの であり，コークス強度推定法の本質的なあのであるが 後者は結晶子の性状関するあのであって活性一不活 性成分の条件以外の問題である。また，高島炭の節下 物は必ずしも穊上物之組成的に変わらず活性一不活性 成分の良否によって招来されたとは思われない。した がって組織学的強度推定法はイットマンの例の第 1 だ けが節下となるようなコークス強度を推定する時に限 って妥当であって高島炭のばあい，あるいは本来膠結 剤として働くべき活性成分が巨大結晶様子となったた めに却って粉化をおてすようなコークスのばあいには 適応されないというととができよう。

既述のように，高島炭では不活性成分が少ないため 壁は切質ではあるが薄く, 孔除が大きいためドラム試 験機で攪拌される際には壁部の弱所から割れていくの ではなく，それよりあマクロのオーダーの弱線……収 縮亀裂, 押し出しの際の亀裂……加ら割れるあのと判 断される, 事実イットマン, 高島の $25 \sim 15 \mathrm{~mm}, 15 \sim$ $6 \mathrm{~mm}$ の肉眼外形を比較すると,イットマンコークス塊 は棈円形〜円形を示すのに対し高島コークス塊は柱状 形をなし，とくに15〜 6 $\mathrm{m}$ mはみな多角形長柱状であ るが，乙れは明らかに収縮裂鐪にそって細片化した柱
状片である。このととからあ明らかなように，不活性 成分一活性成分がよく翏結して強固な壁部をつくるか 否かのほかに生成コークスに収縮亀裂ができやすいか 否かによってもコークス細片化の程度が左右される。 したがってコークス強度推定法にての収縮度のファク ター(亀裂発生難易度ファクター)を加味しなければ十 分な結果を期待できないととは明らかである。ただし， Strength-Index, Composition-Balance Index は各石 炭化度でとの活性一不活性成分適正量比の実測をむと にして計算されたあのであり, 実測値の内容には表現 はされていないけれどあすでに収縮亀裂, 巨大結晶様 子化の剝離などが総合值として含まれていると考えな ければいけない。そてで, 概念として含まれているてれ らの值をどのように表現し, 活性一不活性成分比の総合 值からとり出して強度推定法をくみな扎していくかが 問題となるが，裂罅生成の難易む結晶子剶離化すすべ てコークス固結時における結晶様子の問題に帰せられ る。換言すればコークス強度の一要因は結晶様子の性 状によるということができよう。コークスが固化する ばあいには原炭の石炭化度に応じて, 何ら結晶様子の 晶出しないあの, 陰微晶質のもの, 小粒状, 小桿状ある いは層状結晶様子が陰微晶質基地に混在するあのなど 種々雑多であり, まして数炭種を混炭したばあいには これらがさらに複雑に組合わされるので結晶様子の性 状配列を予測し上記の数值をひきだすととはまてとに 困難である。しかし，一般的には，針状〜小桿状結晶様 子, 層状結晶様子はコークス底面に平行に配列してい るあのが多いので, 除微晶質, 非晶質のあのに比べる と結晶様子がよく発達しているものの方が底面に垂直 に働く収縮力に対して抵抗力は強く, 裂鐻の発達は少 ないであろう。微層状をなお大型の結晶子になると剝 離性が著しくなり蛨に際して弱線として働くことは ありうるので, 原炭の石炭化進捗に伴いコークス壁抵 抗に小 $\rightarrow$ 大 $\rightarrow$ 小経移はあらわれようが，巨視的にみ れば結晶様子晶出部之陰微晶質〜非晶質部を区別測定 し，収縮亀裂との関係を求めれば上述ファクタ一のあ る程度の定量化は可能ではないかと思われる*。両者の 関係資料はまだよく揃ってはいないが**従来の亀裂発

* 吉田雄次は亀裂の発生と成長関する研究を行な い, 亀裂発生因子がコークスの強度と密接な関係 をあっていることを明らかにしている10)。

**1次亀裂，2次亀裂とも插入原炭の組織が均一なた めと生じるので, 石炭組織成分の含有比率を知れ ば指状亀裂発生状態,ないしはコークス強度は求 められるという岩崎の主張には賛成しがたい11。 


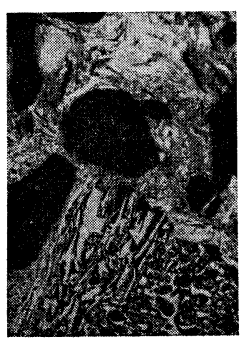

1

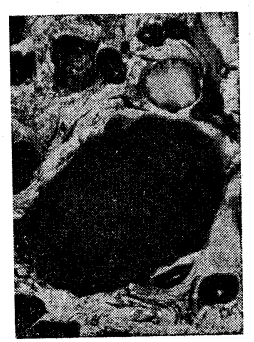

3

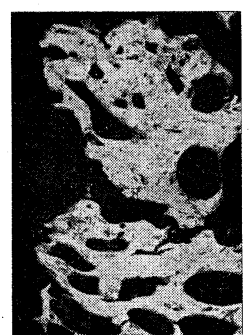

5

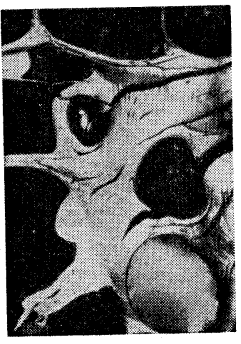

2

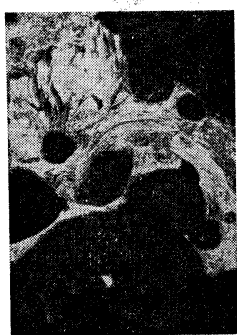

4

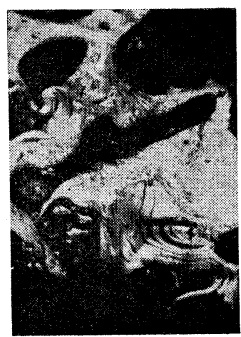

6
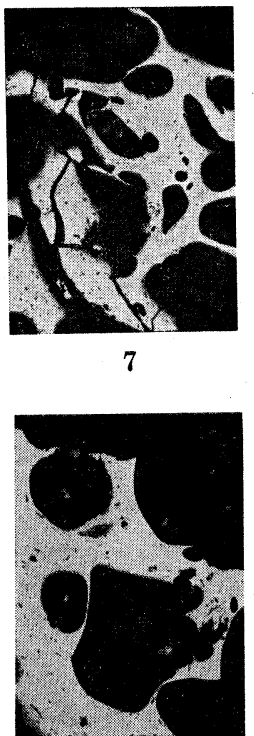

9

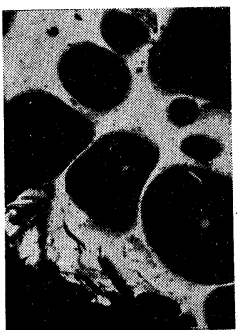

11

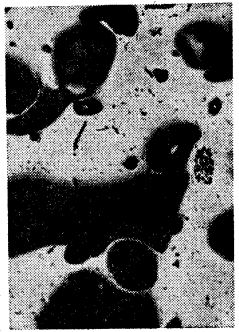

8

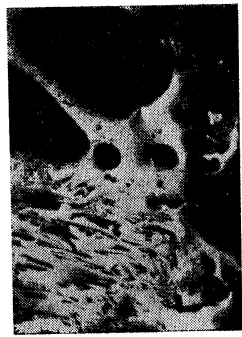

10

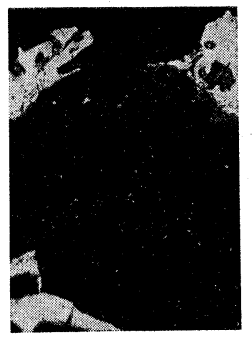

12
1. イットマン $25 \sim 15 \mathrm{~mm}: \times 125$

2. イットマン 25 $15 \mathrm{~mm}: \times 125$

3. イットマン $15 \sim 6 \mathrm{~mm}: \times 125$

4. イットマン $15 \sim 6 \mathrm{~mm}: \times 125$

5. イットマン $15 \sim 6 \mathrm{~mm}: \times 125$

6. イットマン $\quad-6 \mathrm{~mm}: \times 125$

7. 高 島 $15 \sim 6 \mathrm{~mm}\}: \times 125$

8. 高 島 $15 \sim 6 \mathrm{~mm}$ 至

9. 高 島 $-6 \mathrm{~mm}: \times 125$

10. 混炭 $-6 \mathrm{~mm}: \times 125$

11. 混炭 $-6 \mathrm{~mm}: \times 125$

12. 混炭 $-6 \mathrm{~mm}: \times 125$
Fusinite をよく膠結する Cell とは小桿状，微層状結晶様子が晶出して いる。 pore も小さい。

層状大型結晶様子 (gross flächig), 1 部は薄壁をなす。

孔隙周辺飞晶出した微層状結晶様子と, 割れ易い薄壁。

孔隙周辺の微層状結晶様子飞は明暸な流理構造が著しい。

周辺部のコークス組織, よく熔結し, 孔隙も比較的小さいが大孔隙の所 にすでKクラックが生じている。

微層状結晶様子の所で粉化している。壁は比較的薄い。

壁，孔隚の状態とも25〜 $15 \mathrm{~mm}$ の屯のと差異はない。壁には微粒の結晶 子が晶出している。

よく流動したために壁は薄く，また孔隙は大きい。少量のインナートが 散在している。

イットマンの Fusinite をイットマン，高島の活性成分で膠結している が，不十分なために粉化したもの（半クロスニコル）

両炭種の活性成分がよく混合していないので高島炭由来の薄壁部で粉化 したもの

両炭種活性成分の不足部分で炭質頁岩をよくセメントできず粉化してい る。 
生に関する研究を, 再度結晶様子の面から追求すれば コークス強度推定法適応の限界を知るととができ, ひ いてはこの推定法をより完全にすることができよう。

$$
\text { 4. 結論 }
$$

コークス強度を組織学的に推定する方法は各国で研 究されているが，筆者らあ同じような観点から推定法 を検討し，独自の簡便法を開発してかなりの成果を収 めることができた。しかしながら低石炭化度を原炭と してコークスを作るばあい，とくに国内炭をコークス 原炭としたばあいには，潰裂強度 $15 \mathrm{~mm}$ 指数の実測值 々計算值に大きな偏差があらわれ，開発した方法にな お不完全さのあるととを認めざるをえなかった。そこ で，乙の推定法の根本となった活性成分不活性成分の 質・量比がコークス強度を決定するものか否かを $15 \mathrm{~m}$ $\mathrm{m}$ 節上・節下物について検討し，つぎのような結果を えた。

1 ）活性成分一不活性成分の量的関係によってコー クス強度の大勢はきまるが，活性成分そのもの の固化（結晶化）の性状が強度にも著しく影響 する。

$2 ）$ 収緧裂罅生成の難易など, 石炭組織成分の熱行 動よりマクロな要因屯強度に大きくあらわれて いる。
3 ）陰微晶様〜非晶様質なコークス壁よりあ結晶様 質壁は収縮しにくくクラックは生じにくい。現 在の所収縮裂罅生成度の数值を見出しえない が, この数值をくみこめばコークス強度推定法 はより精度の高いあのになろう。

$$
\text { 文献 }
$$

1) N. Schapiro \& R. J. Gray; Proc. of the Illinois Mining Inst., 68 th Year, 83 97 (1960)

2) N. Schapiro, R. J. Gray \& G. R. Eusner, Blast Furnace, Coke Oven and Row Materials Committee, Proc. 20, p. 89 112 (1961)

3) N. Schapiro \& R. J. Gray, Joar. Inst. of Fuel. 37, 6, p. 234 242 (1964)

4) J. A. Harrison; Proc. of the Illinois Min. Inst. 96 th Year, p. 17 43 (1961)

5) J.A. Harrison, Illinois Geol. Survey Circ. 366, p. 1 20 (1964)

6）高橋良平, 然協誌, 41, 418 (1962)

7) 高橋良平, 竹下健次郎：燃協誌, 43, 444 (1964)

8) G. H. Taylor, Fuel, 40, 6, p. 465 472 (1961)

9) H. Freund, Handbuch der Mikroskopie in der Technik, Bd II, Teil 1, (1952)

10) 馬場有政編, 石炭科学の進歩, 第 2 集, p. 169 214 (1956)

11）馬場有政編, 石炭科学の進歩, 第 2 集 p. 142 145 (1956)

\title{
Some Problems on Coke-strength Standing on the Coal Petrology
}

\author{
by Ryohei Takahashi and Toshiaki Nagai
}

(Kyushu University)

SYNOPSIS :-Quantitative prediction method of coke-strength from coal petrographic analysis of row coals has been developed in many countries and is still being improved. One method developed by N.Schapiro of the U.S. Steel Corp. is really worthy and indeed in use for the routine works. In agreement to the N. Schapiro's method, we have studied the same subject using all the kinds of imported and domestic coals, and made the expedient diagram for calculation of coke-strength. It is, however, not enough for the cokes produced from the low rank coals. We reinvestigate, therefore, "Gefüge" of the screened coke under the microscope, taking the quantitative-, and qualitative relationships between reactive and inert macerals into consideration, which are considered to play definite roles on cokestrength. The results obtained may throw a light on the the problem, whether prediction of coke-strength from coal petrographical analysis is available for all cokes produced from all sorts of coals.

They are summarized as follows;

1) Coke-strength is primarily affected by the quantitative and qualitative relationships be- 
tween reactive and inert macerals. The character and distribution of crystallites in cell-walls of cokes, however, have an influence indirectly upon strength of cokes.

2) Shrinking crack has a tendency that occurs more easily in amorphous or microcrystalline cell-wall than in well crystallized one. The crack is of macroscopic order and occurs independently from the sort of macerals.

3) Evaluation of crack-genesis is not yet established, but coupling the value with the one from coalpetrographical analysis, the prediction of coke-strength may become more accurate and usefull for the routine cokemaking work. 